Review

\title{
Neurological Sequelae in Patients with COVID-19: A Histopathological Perspective
}

\author{
Francesco Fisicaro ${ }^{1,+} \oplus$, Mario Di Napoli ${ }^{2,+t} \neq \oplus$, Aldo Liberto ${ }^{1}$, Martina Fanella ${ }^{2}$, Flavio Di Stasio ${ }^{3} \oplus$,

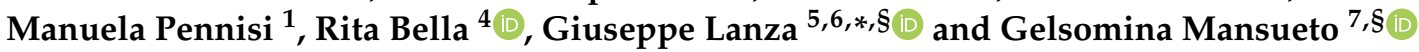

Citation: Fisicaro, F.; Di Napoli, M.; Liberto, A.; Fanella, M.; Di Stasio, F.; Pennisi, M.; Bella, R.; Lanza, G.; Mansueto, G. Neurological Sequelae in Patients with COVID-19: A Histopathological Perspective. Int. J. Environ. Res. Public Health 2021, 18, 1415. https://doi.org/10.3390/ ijerph18041415

Academic Editor: Marco Scarselli

Received: 29 December 2020

Accepted: 29 January 2021

Published: 3 February 2021

Publisher's Note: MDPI stays neutral with regard to jurisdictional claims in published maps and institutional affiliations.

Copyright: (c) 2021 by the authors. Licensee MDPI, Basel, Switzerland. This article is an open access article distributed under the terms and conditions of the Creative Commons Attribution (CC BY) license (https:/ / creativecommons.org/licenses/by/ $4.0 /)$.
1 Department of Biomedical and Biotechnological Sciences, University of Catania, Via Santa Sofia 97, 95123 Catania, Italy; drfrancescofisicaro@gmail.com (F.F.); aldoliberto@gmail.com (A.L.); manuela.pennisi@unict.it (M.P.)

2 Department of Neurology and Stroke Unit, San Camillo de' Lellis General Hospital, Viale Kennedy 1, 02100 Rieti, Italy; mariodinapoli@katamail.com (M.D.N.); fanella.martina@gmail.com (M.F.)

3 Department of Neurology and Stroke Unit Cesena-Forli, Bufalini Hospital, AUSL Romagna, Viale Ghirotti 286, 47521 Cesena, Italy; flavds@libero.it

4 Department of Medical and Surgical Sciences and Advanced Technologies, University of Catania, Via Santa Sofia 87, 95123 Catania, Italy; rbella@unict.it

5 Department of Surgery and Medical-Surgery Specialties, University of Catania, Via Santa Sofia 78, 95123 Catania, Italy

6 Department of Neurology IC, Oasi Research Institute-IRCCS, Via Conte Ruggero 78, 94018 Troina, Italy

7 Department of Advanced Medical and Surgical Sciences (DAMSS), University of Campania "Luigi Vanvitelli", Piazza L. Miraglia 2,80138 Naples, Italy; gelsomina.mansueto@unicampania.it

* Correspondence: giuseppe.lanza1@unict.it; Tel.: +39-095-3782448

+ Equal contribution (in either order).

$\ddagger$ Currently, at the Neurological Service, SS. Annunziata Hospital, Viale Mazzini 110, 67039 Sulmona, Italy.

$\S$ Equal contribution (in either order).

Abstract: Background: Neuroinvasive properties of SARS-CoV-2 have allowed the hypothesis of several pathogenic mechanisms related to acute and chronic neurological sequelae. However, neuropathological correlates have been poorly systematically investigated, being retrieved from reports of single case or limited case series still. Methods: A PubMed search was carried out to review all publications on autopsy in subjects with "COronaVIrus Disease-19" (COVID-19). Among them, we focused on histological findings of the brain, which were compared with those from the authors' autoptic studies performed in some COVID-19 patients. Results: Only seven studies reported histological evidence of brain pathology in patients deceased for COVID-19, including three with reverse transcription-quantitative polymerase chain reaction evidence of viral infection. All these studies, in line with our experience, showed vascular-related and infection-related secondary inflammatory tissue damage due to an abnormal immune response. It is still unclear, however, whether these findings are the effect of a direct viral pathology or rather reflect a non-specific consequence of cardiovascular and pulmonary disease on the brain. Conclusions: Notwithstanding the limited evidence available and the heterogeneity of the studies, we provide a preliminary description of the relationship between SARS-CoV-2 and brain sequelae. Systematic autoptic investigations are needed for accurate detection and adequate management of these patients.

Keywords: SARS-CoV-2; COVID-19; neuroinvasion; neuropathology; pathogenesis; autopsy; histopathology; long-term prognosis; outcome

\section{Introduction}

The recently emerged Severe Acute Respiratory Syndrome-Coronavirus-2 (SARSCoV-2) has shown several neuroinvasive properties that have allowed the hypothesis of different pathogenic mechanisms related to both acute and chronic neurological sequelae of the "COronaVIrus Disease-19" (COVID-19). However, the neuropathological correlates 
have been poorly systematically investigated yet, being essentially retrieved from reports of single case or limited case series still. Moreover, a comprehensive assessment of the neuropathological features observed in the brain of patients deceased for central nervous system (CNS) involvement of COVID-19 is currently lacking.

Here, we reviewed and discussed the current findings from neuropathological examinations performed in deceased patients for COVID-19, with the aim of providing hints for accurate detection and adequate management. We also compared the literature results with the authors' autoptic studies carried out in some infected patients.

\subsection{Current Neuropathogenic Hypotheses}

In COVID-19, neuroinvasion can take place both in the early and advanced stages [1]. Olfactory mucosa and olfactory bulb can be affected by SARS-CoV-2 entry via the nose, i.e., the transcribrial route. The nasal load can become a source that affects the olfactory bulb and cleft by an initial infection and inflammation around the cells within the olfactory mucosa, causing anosmia. Then, the viral load resulting from rupture of the cells extending from the nasal mucosa to the olfactory bulb via the cribriform plate can be transported by the cerebrospinal fluid (CSF) to the adjacent and distant areas of the CNS. As CSF is present in the subarachnoid space of the meninges directly supporting the olfactory bulb, the virus can reach the CNS without breaching the blood-brain barrier (BBB) [2].

However, earlier pathological and clinical studies have produced conflicting results regarding the presence of the virus in the brain or the CSF. Some authors, indeed, identified the SARS-CoV-2 RNA in autoptic brain exams or the CSF of encephalopathic patients, although at a very low level [3]. Conversely, other studies did not detect any viral sign, although evidence of CSF inflammation was present [4,5], suggesting an artifact or contamination [6].

At the structural level, surface glycoproteins of Coronaviruses (CoVs), such as the spike protein, are composed of 14 binding residues directly interacting with the human angiotensin-converting enzyme-2 (ACE2) receptor. ACE2 is also used as the main docking receptor by SARS-CoV-2, which needs a proteolytic process of the spike protein by the transmembrane protease serine-2 for an effective cell attack [7]. Therefore, ACE2 is not only an enzyme but also a functional surface receptor through which SARS-CoV-2 enters the host cells and highly expressed in the heart, kidneys, lungs, and blood cells. ACE2 is also a key regulator of the renin-angiotensin-aldosterone system (RAAS). SARS-CoV-2 can cause an ACE/ACE2 balance disruption and RAAS activation, which eventually leads to disease progression, especially in patients with comorbidities, such as hypertension, diabetes mellitus, and cardiovascular diseases [8].

The BBB may represent the second modality of entry of SARS-CoV-2, and two main theories have been hypothesized for the BBB crossing. The first mechanism would act through a cellular transport across vascular endothelium [9]; as soon as the virus attacks vascular and neuronal cells, it would interact with the ACE2 on the vessels, neurons, and glia, then starting a budding cycle that further damages both neuronal and vascular tissues [1]. The second hypothesis relies on the so-called "Trojan horse mechanism", through the infection of leukocytes passing across the BBB [10]. Since the ACE2 is expressed by granulocytes, monocytes, and lymphocytes, SARS-CoV can infect them [11-14], and SARS-CoV-2 might act with the same modality. Furthermore, systemic inflammation related to COVID-19 would enhance the BBB permeability, thus promoting CNS invasion by the immune cells infected [15].

Lastly, it cannot be excluded that SARS-CoV-2 may persist in some CNS resident cells and clinically act as a cofactor of clinical exacerbations. Indeed, CoVs have been found in neurological disorders, such as multiple sclerosis (MS), optic neuritis, and Parkinson's disease [16-19]. In parkinsonian patients, CSF was blinded analyzed by the enzyme-linked immunosorbent assay for antibody response to four $\mathrm{CoV}$ antigens (mouse hepatitis virus JHM and A59, and human coronavirus 229E and OC43) [16], whereas in MS patients, intrathecal antibody synthesis to OC43 and $229 \mathrm{E}$ viruses was detected in $41 \%$ and $26 \%$, 
respectively [18]. Accordingly, it was suggested that the persistence of $\mathrm{CoV}$ infection might pathogenically contribute to the onset and course of these disorders. For instance, it is known that some infective agents may trigger MS, viruses being the most likely involved in some genetically predisposed patients [20]. Conversely, among CSF from 37 subjects with optic neuritis, only four patients and one control were positive for CoV 229E and none for OC43, thus not providing evidence for an etiological role of human CoVs [19].

Figure 1 summarizes the main pathophysiological mechanisms proposed in patients with COVID-19 and acute and long-term CNS involvement.

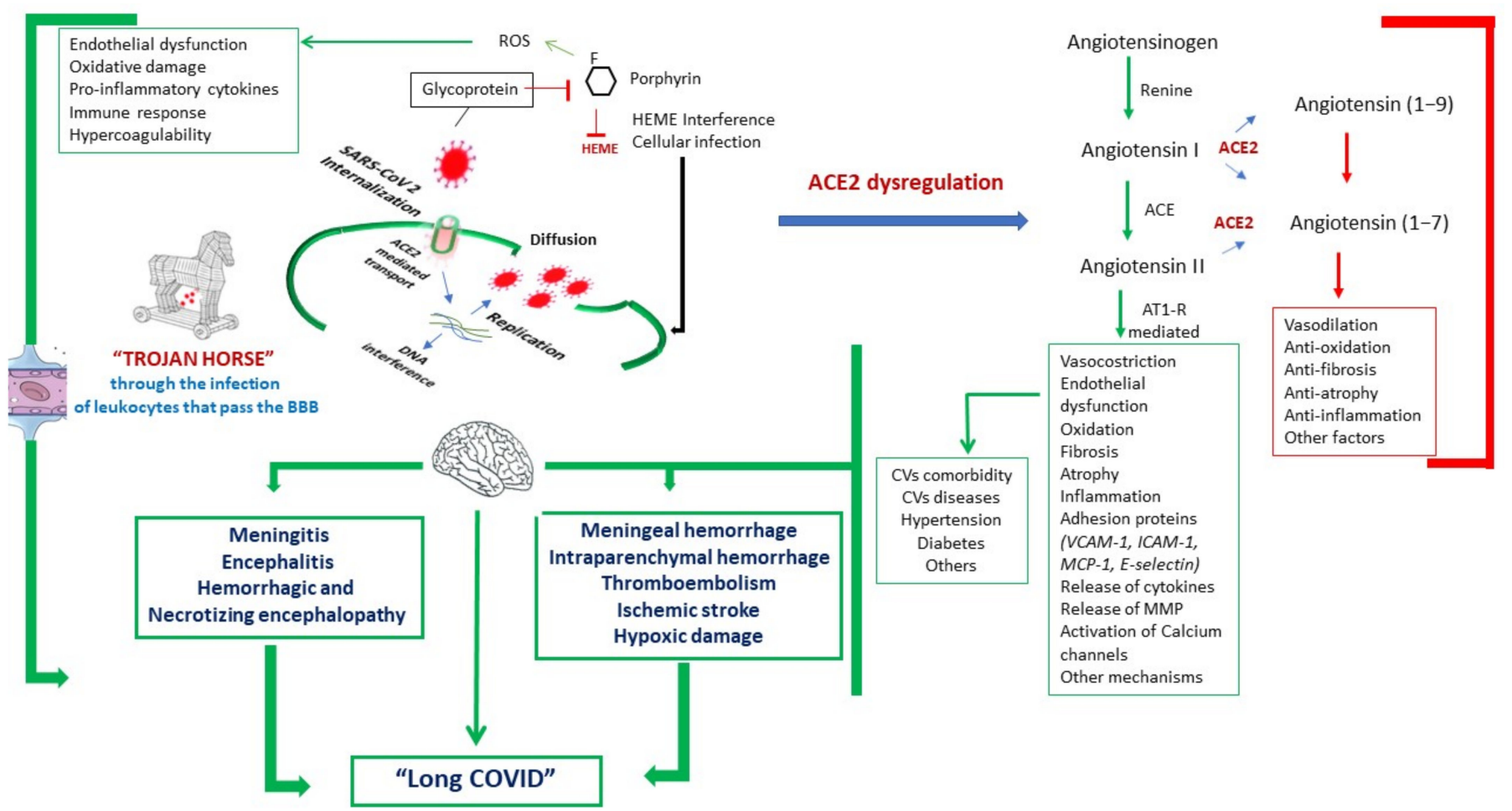

Figure 1. Main pathophysiological mechanisms proposed in patients with COronaVIrus Disease-19 (COVID-19) and related acute and long-term neurological manifestations. Angiotensin-converting enzyme-2 (ACE2) and iron chelated with any porphyrin, irrespective of the valence state of the iron atom (HEME) dysregulation, as well as direct action on vascular endothelium, immune response, and inflammation (with the subsequent release of inflammatory mediators), and the "Trojan horse hypothesis" (i.e., leukocytes-carriers of infection through the blood-brain barrier) have been proposed as the main mechanisms responsible for brain lesions. The inhibitory pathways are shown in red, while the activatory pathways are indicated in green, along with morphological changes responsible for cardiovascular and brain diseases, especially in comorbid patients. Legend: ACE2: angiotensin converting enzyme-2; AT1-R: angiotensin II receptor type; BBB: blood-brain barrier; CVs: cardiovascular manifestations; HEME: iron chelated with any porphyrin, irrespective of the valence state of the iron atom; ICAM-1: intercellular adhesion molecule 1; MCP-1: monocyte chemoattractant protein-1; MMP: matrix metalloproteinase; ROS: reactive oxygen species; VCAM-1: vascular cell adhesion molecule 1.

\subsection{Overview of the Main Neurological Manifestations}

Although neurological complications may arise from a direct effect of SARS-CoV-2, they usually reflect a systemic response to the infection, with severe cases of COVID-19 more often producing CNS complications with respect to mild forms (45.5\% vs. 30\%) [21]. Moreover, most of these patients are in the older age group, and exhibit comorbidities, especially hypertension, and the neurological involvement can occur independently of the respiratory manifestations [22,23].

Globally, asthenia, myalgia, headache, anosmia, and ageusia are the most common symptoms, followed by encephalopathy, stroke, and seizures [9]. In extreme cases, some patients may exhibit encephalitis, flaccid paraparesis, and coma [22]. Of note, telemedicine 
is no longer a futuristic concept, being the new normal for an increasing number of medical and surgical specialists during the pandemic [24].

A recent meta-analysis concluded that among 70 patients with COVID-19 and neurological manifestations (mean age $61.9 \pm 17.7$ years, $60.6 \%$ male), $39(53.4 \%)$ had a stroke, $18(24.7 \%)$ a Guillain-Barré syndrome or its variants, 11 (15.1\%) encephalopathy, meningitis, encephalitis, or myelitis, and $5(6.8 \%)$ seizures. Neurological disorders presented after $8.1 \pm 6.8$ days from the onset of infection. The average rate of mortality was $17.8 \%$ (mortality rate of stroke $25.6 \%$ ), whereas chemosensory dysfunction occurred in $59.9 \%$ and $57.5 \%$ of patients with anosmia and ageusia, respectively [25].

More recently, a systematic search on 19 studies and $>12,000$ adult patients with laboratory-confirmed COVID-19 [26] found that headache was reported in 7.5\% of patients, dizziness in $6.1 \%$, hypo-anosmia and gustatory dysfunction in $46.8 \%$ and $52.3 \%$, respectively, whereas symptoms of muscular injury ranged between $15 \%$ and $30 \%$. Three studies reported a radiologically-confirmed acute cerebrovascular disease in $2 \%$ of patients [26].

Older subjects or those with pre-existent cognitive impairment, several comorbidities, past medical conditions, poor pre-morbid functional independence, malnutrition, concomitant infections, or multiple vascular risk factors are also at higher risk for altered consciousness and encephalopathy when affected by COVID-19 [27-29]. Endocrine or metabolic disorders, such as hypo-hypercalcemia, hypo-hypernatremia, hypo-hyperglycemia, liver and/or kidney dysfunction, and sepsis confer a further risk [30].

An acute hemorrhagic necrotizing encephalopathy (AHNE) was described in a COVID19 patient [31]. Brain magnetic resonance imaging revealed multifocal and symmetric contrast-enhanced hemorrhagic lesions in the thalamus, mesial temporal region, and insula, bilaterally [31]. A similar case occurred in a previously healthy 44-year-old woman [32]. A posterior reversible encephalopathy-like syndrome, with reversible cortical blindness [33] and mild encephalopathy, was also described [34]

Older individuals with COVID-19 are at higher risk for neurovascular events [35]. In a retrospective cohort of 221 subjects [36], eleven (5\%) underwent ischemic stroke, one $(0.5 \%)$ cerebral hemorrhage, and one $(0.5 \%)$ cerebral venous thrombosis. Other authors reported five patients with stroke (of ischemic origin in four of them) in the context of severe COVID-19, thrombocytopenia, increased D-dimer, and multiple organ failure [29]. Of note, a previous investigation in the USA observed that young persons $(<50$ years) more likely underwent large-vessel strokes during the course of COVID-19, thus showing that all age groups can be affected [37]. Increased markers of inflammation and a state of hypercoagulability seem to be a feature of severe forms [29]. Indeed, systemic inflammation associated with the infection, vasculitis, and thrombosis is known to enhance the risk of stroke [38]. Finally, both systemic vasculitis and CNS vasculitis were autoptically documented in SARS-CoV patients [39].

Lastly, smell and taste disorders are often complained about by COVID-19 patients and can manifest suddenly [40]. In Italy, $19.4 \%$ of subjects had some forms of anosmia and ageusia [41], and in a registered study on 12 European centers, including 417 patients with mild-to-moderate COVID-19, chemosensory dysfunction had a prevalence of $85.6 \%$ (anosmia) and 88\% (ageusia) [42]. Notably, olfactory dysfunction was mentioned as the onset symptom in $12 \%$ of them, without any runny nose or nasal obstruction in $18 \%$ [42].

\subsection{Autopsy, Brain Sampling, and Histopathological Assessment in COVID-19 Patients}

Unlike other organs and tissues, which can be easily sampled by biopsy, a comprehensive histopathological assessment of the nervous system requires a detailed examination of both the CNS and peripheral nervous system (PNS). At the onset of the pandemic, several countries, including Italy, did not allow autopsies in the attempt to contain the risk of infection and its spread. Later, although many local governments and scientific communities appreciated the missed opportunity of collecting histopathological data, the number of autopsies has only increased slowly [43], probably due to the limited pathologists trained in the brain and the few centers able to guarantee the safety of the mortuary staff. According 
to the international guidelines [44-46], indeed, autopsies must be performed within a certified biosafety level 3 Autopsy Room, and mortuary staff must be equipped with personal protection equipment (disposable headgear, double pair of disposable gloves, cut-resistant protective gloves, respiratory filter FFP3 protection, Tyvek coverall suits). During brain and spinal cord removal, particular care is also needed to avoid bone aerosolization.

Another relevant concern regards the sampling. It is often unclear if it has been sufficient and if standard protocols have been adopted; therefore, the microscopic results obtained may not be comparable [47]. Furthermore, data appear to be heterogeneous since only a few papers have identified the virus with the reverse transcription-quantitative polymerase chain reaction (RT-qPCR). Even when the assay was executed, it is also uncertain whether the genome could be exclusively identified with that of SARS-CoV-2 [47].

To date, the management of neurological symptoms and therapy of COVID-19 patients seem to be more challenging than pulmonary and cardiovascular manifestations, those being more systematically investigated [48-53]. Furthermore, in the pandemic scenario, some symptoms, and signs of CNS involvement, e.g., those underlying meningitis or encephalitis, were not always correctly diagnosed and promptly managed. Therefore, the questions we want to draw attention to are the following: How many cases were actually attributed to a direct invasion of the CNS by SARS-CoV-2? How many cases have been not diagnosed or misdiagnosed due to a failure to identify the virus in the CSF or at the post-mortem examination? Can we make a reliable differential diagnosis between direct viral damage and superposition damage by other causes or etiological agents?

To properly answer these questions, it should be preliminarily stated that, although autopsies are still scarce compared to the entity of the pandemic, the most common pathological lesions in COVID-19 appear to be similar to those seen in the context of other viral and systemic diseases associated with cardiovascular involvement. Based on our autopsy experience [54-58] and current evidence from the literature, it seems that morphological data are still limited to a few cases of meningitis or necrotizing encephalopathy [3,30,58]. More recently, it has also been hypothesized that neuropathological changes might be the consequence of direct or immune-mediated damage of the virus, although a secondary lesion from the interaction through the ACE2 receptor or interference with the HEME formation cannot be excluded (Figure 1), as well as an indirect injury from a systemic dysfunction [50,59-63]. Unbalanced homeostasis, immune-mediated action, and damage from cytokines release and inflammatory mediators (i.e., the "cytokine storm") seem to contribute to neurological deficits [50,59-63]. It is also likely that hypoxemia plays a role in many patients with encephalopathy, it being secondary to metabolic derangements due to multiple organ failure or medication effects.

Nevertheless, it should be taken into account that peripheral biomarkers showed non-specific signs of neuronal damage and reactive gliosis in moderate-to-severe patients with COVID-19. This does not seem to suggest a distinctive neuropathogenesis of SARSCoV-2 [64]. Similarly, weak evidence supports direct viral damage, which presupposes its capacity for overcoming the BBB. Moreover, SARS-CoV-2 can infect different cell types, and data on the involvement of endothelial cells alone are enough to explain most of the pulmonary, cardiovascular, and other organ damage, including the CNS. Additional data come from the few pathological findings described in subjects with SARS-CoV and Middle East Respiratory Syndrome (MERS)-CoV: histologically, edema and non-specific neuronal degeneration were mostly observed at patients' autopsies [11,39,65-67].

\section{Data Sources and Selection}

A PubMed (MEDLINE) review was carried out to identify all studies dealing with autopsies performed in COVID-19 patients. The following search terms were used, from database inception to December 2020: COVID-19, SARS-CoV-2, autopsy, neuropathology, histology, morphology, encephalopathy, ischemic stroke, intracerebral hemorrhage, gliosis, necrotizing encephalopathy, encephalitis, myelitis, and inflammation. 
A total of more than 11,000 articles, including those listed in the references of the retrieved studies, were found originally. We then excluded the following items: all publications not dealing with COVID-19 autopsy or neuropathology; all studies different from original articles (e.g., reviews, case report/case series, letters, commentaries, etc.); all preclinical studies or research performed on animals or cell cultures; non-English written papers; any other publication that did not comply with the goal of the present review. After this process, 46 studies performed autopsy: 39 showing pulmonary, cardiovascular, or other organ involvement (Appendix A), and 7 showing brain pathology (Table 1). Among them, only 3 autopsy studies demonstrated a RT-qPCR-positive viral infection [68-70].

Table 1. Relevant autopsy studies performed during COronaVIrus Disease-19 (COVID-19) pandemic.

\begin{tabular}{|c|c|c|c|c|c|}
\hline $\begin{array}{c}\text { Study } \\
\text { [References] }\end{array}$ & $n ; \operatorname{Sex}$ & Age (Years) & $\mathrm{P} / \mathrm{CV} / \mathrm{C}$ & RT-qPCR+ & CNS Involvement \\
\hline $\begin{array}{l}\text { Stoyanov et al., } \\
2020 \text { [68] }\end{array}$ & $1 ; \mathrm{F}$ & 77 & $\sqrt{ }$ & $\sqrt{ }$ & Acute necrotizing encephalitis \\
\hline $\begin{array}{l}\text { Al-Dalahmah et al., } \\
2020 \text { [71] }\end{array}$ & $1 ; \mathrm{M}$ & 73 & $\sqrt{ }$ & & $\begin{array}{c}\text { Neuronal damage } \\
\text { Neuronophagy } \\
\text { Perivascular lymphocytes } \\
\text { Microglial reaction }\end{array}$ \\
\hline $\begin{array}{l}\text { Paniz-Mondolfi } \\
\text { et al., } 2020 \text { [69] }\end{array}$ & $1 ; \mathrm{M}$ & 74 & & $\sqrt{ }$ & $\begin{array}{l}\text { Cerebrospinal fluid negative } \\
\text { No data about the detection of } \\
\text { histological lesion }\end{array}$ \\
\hline $\begin{array}{l}\text { Reichard et al., } \\
2020 \text { [72] }\end{array}$ & $1 ; \mathrm{M}$ & 71 & & & $\begin{array}{c}\text { Acute disseminated perivascular } \\
\text { encephalomyelitis } \\
\text { Hemorrhagic lesions } \\
\text { Microinfarctions }\end{array}$ \\
\hline $\begin{array}{c}\text { Bryce et al., } 2020 \\
\text { [73] }\end{array}$ & $\begin{array}{c}67 \text { (20 brains); } \\
38 \mathrm{M}\end{array}$ & $\begin{array}{l}\text { Median: } 69.0 \\
\text { IQR: } \\
(34.0-94.0)\end{array}$ & $\sqrt{ }$ & & $\begin{array}{c}\text { Disseminated micro thrombosis } \\
\text { Ischemic infarcts } \\
\text { Hemorrhage }\end{array}$ \\
\hline $\begin{array}{l}\text { Solomon et al., } \\
2020 \text { [6] }\end{array}$ & $18 ; 14 \mathrm{M}$ & $\begin{array}{l}\text { Median: } 62.0 \\
\text { IQR: } \\
(53.0-75.0)\end{array}$ & & & $\begin{array}{l}\text { Acute cerebral and cerebellar } \\
\text { hypoxia-related lesions } \\
\text { Neuronal loss within the cerebral } \\
\text { cortex, hippocampus, and } \\
\text { cerebellar Purkinje cell layer } \\
\text { Perivascular lymphocytes } \\
\text { Focal leptomeningeal } \\
\text { inflammation }\end{array}$ \\
\hline $\begin{array}{l}\text { Matschke et al., } \\
2020 \text { [70] }\end{array}$ & $43 ; 27 \mathrm{M}$ & $\begin{array}{l}\text { Median: } 76.0 \\
\text { IQR: } \\
(70.0-86.0)\end{array}$ & & $\sqrt{ }$ & $\begin{array}{c}\text { Ischaemic lesions } \\
\text { Astrocytosis } \\
\text { Microglia activation } \\
\text { Cytotoxic T lymphocytes at the } \\
\text { brainstem, cerebellum, basal } \\
\text { ganglia, and olfactory bulb }\end{array}$ \\
\hline
\end{tabular}

Legend: $n$ : number of patients; F: female; M: male; CNS: Central Nervous System; IQR: interquartile range; P: pulmonary involvement; CV: cardiovascular involvement; C: coagulopathy; RT-qPCR: reverse transcription-quantitative polymerase chain reaction.

\section{Results and Discussion}

\subsection{Main Findings}

Table 1 and Appendix A report the main autopsy studies during the COVID-19 pandemic. As expected, pulmonary and cardiovascular lesions were those investigated the most and basically appeared not to be different from those previously described in SARS-CoV and MERS-CoV [51-53]. Diffuse alveolar damage, myocarditis, myocardial infarction, thromboembolism, disseminated intravascular coagulation, among others, have been reported. Of note, thromboembolism and ischemic stroke have been explained in the context of acute events affecting the cardiovascular system. Large vessel occlusion by 
hypercoagulability and cerebral vasculitis were also common [74]. Taken together, these findings are in line with the authors' experience (Figure 2).
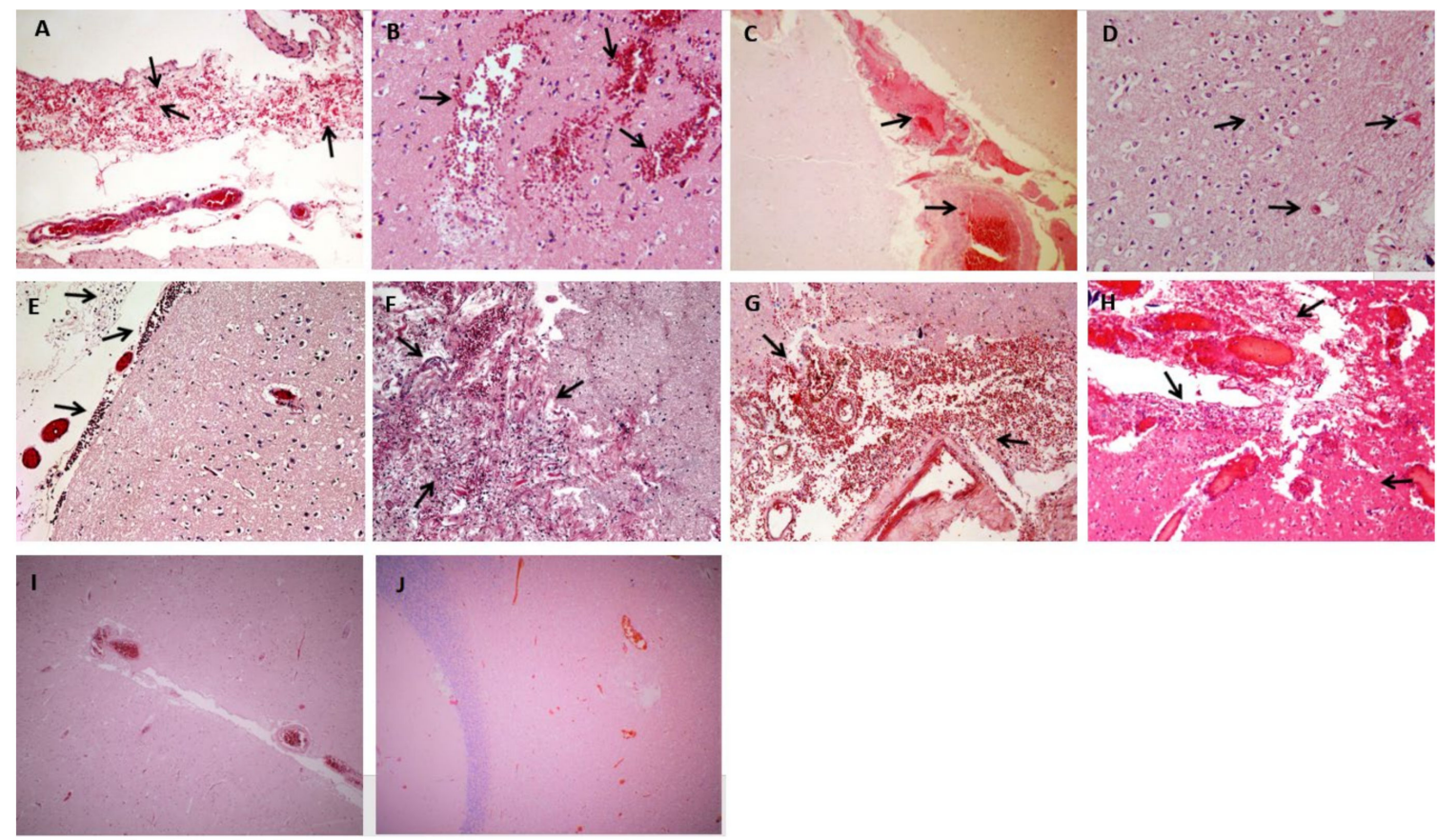

Figure 2. Main anatomopathological findings from authors' autoptic studies carried out in some COVID-19 patients. (A-D): vascular-related changes; (A): meningeal erythrocyte extravasations (arrows) [Hematoxylin and eosin $(\mathrm{H} \& \mathrm{E})$ stain $\times 10$ ]; (B): focal and multiple intraparenchymal erythrocyte extravasations (arrows) (H\&E stain $\times 40$ ); (C): fibrinoid material aggregated in the vessel lumen (thrombo-embolus), with associated pale parenchymal areas as from ischemic damage in the first phase (arrows) (H\&E stain $\times 10)$; (D): initial transformation of neuronal cytoplasm and nucleus with the presence of pink neurons from hypoxia (arrows) (H\&E stain $\times 40)$. $(\mathbf{E}-\mathbf{H})$ : infection-related changes $(\mathrm{H} \& \mathrm{E}$ stain $\times 20)$; $(\mathbf{E})$ : inflammatory lymphomonocyte infiltrate in meningitis (arrows); (F): area of inflammatory infiltrate with neuronal destruction and reactive aspects (arrows); (G,H): combined aspects that are often associated in hemorrhagic $(\mathbf{G})$ and necrotizing $(\mathbf{H})$ encephalopathy, characterized by erythrocyte extravasations, mainly in perivascular regions, with areas of adjacent intraparenchymal necrosis and more or less evident inflammatory rate (arrows). (I,J): normal brain findings (H\&E stain $\times 10)$; (I): cerebral cortex, near a sulcus; $(\mathrm{J})$ : cerebral cortex, near the hippocampus.

It clearly emerges from these studies that the CNS represents a relevant target in the disease course of some patients [47], whose brain might be affected by both vascular-related changes and/or infection-related changes. Indeed, the consensus seems to converge on a little or no direct COVID-19 brain damage (i.e., "pure" encephalitis), a relevant contribution of thrombo-embolic vascular changes, a still debatable consequence of the "cytokine storm" in very ill elderly persons, and a few but severe encephalopathic/encephalitis syndromes of unknown causation, although rarely found to be common or representative. Nevertheless, only few of the radiologically and histopathologically identified lesions can be clearly attributed to a vascular injury, usually in the context of vascular comorbidities or risk factors predisposing to ischemic or hemorrhagic conditions. Therefore, performing a brain autopsy in COVID-19 is relevant for the differential diagnosis between a secondary vascular injury related to SARS-CoV-2 infection and primary direct virus damage [47].

Up to now, the few autopsy studies focused on the neurological involvement of COVID-19 may be ascribed to the relatively few deaths from neurological complications compared to those from pulmonary or cardiovascular disease, as well as to purely technicalprocedural reasons or safety-related issues to biopsy or extensive organ examination. Therefore, these considerations should be taken into account when considering the global epidemiology and the estimation of neurological complications causing death in COVID19 and the effort to make a clear distinction between direct damage to the CNS from a 
secondary cerebral lesion due to associated comorbidities and systemic viral dissemination. Moreover, recent clinical reviews demonstrated that SARS-CoV-2 affects not only the CNS but also the PNS and muscles [66,75-78].

Based on the clinical studies and the limited neuropathological data, CNS histopathology encompasses hypoxic/ischemic encephalopathy, activated microglial cells with variable infiltration of perivascular T lymphocyte, cerebrovascular diseases, AHNE, encephalitis/meningitis, acute myelitis, demyelinating disorders, and PNS involvement $[21,68,71,73$, 79-115], with histologically documented lesions in some studies [6,11,68,69,71-73].

Hypoxic/ischemic encephalopathy causes several changes to the brain secondary to a combination of neuroinflammatory response, decreased cerebral oxygen supply due to pneumonia during the acute phase of infection, and systemic metabolic disorders. Accordingly, $\mathrm{CoV}$ infections, including that by SARS-CoV-2, have been diffusely described in association with a "cytokine storm syndrome". Clinically, symptoms are dysphoria, headache, delirium, confusion, mental disorder, loss of consciousness, and coma in severe cases. This histopathological pattern seems to be the most common correlate in COVID-19 patients with clinical CNS involvement [116].

Regarding acute neurovascular accidents and their sequelae, SARS-CoV-2 is able to induce a systemic inflammatory response and a hypercoagulable state, as indexed by an increase in D-dimer, a prolongation of the prothrombin time, and disseminated intravascular coagulation, which confer a greater risk of ischemic and/or hemorrhagic complications [117]. Severe COVID-19 cases, therefore, are at high risk of thrombosis secondary to an indirect hypercoagulable state and a direct vascular endothelial damage [116]. In AHNE, coagulative neuronal necrosis, reactive gliosis, and perivascular lymphocytic infiltration with cell debris or inclusions were the main histological aspects [68].

Regarding meningitis and encephalitis, albeit viral encephalitis was expected to be one of the most common complications, the current evidence indicates that it is quite rare in COVID-19. In the encephalomyelitis/acute disseminated perivascular encephalomyelitis, processes of acute inflammation involving the CNS and causing demyelination were described in association with neuronal damage and some vascular lesions, such as multifocal hemorrhage and/or micro-infarcts and perivascular inflammation with histiocytes and astrocytosis infiltration. Up to now, however, clinically diagnosed cases are very scarce, although those reported were not confirmed at the histopathological exam. In general, it is also difficult to diagnose viral CNS diseases, mainly because of symptom variability, a paucity of specific markers, and challenges in distinguishing it from other viral or even non-viral encephalitis, as well as from a non-specific encephalopathy related to a systemic viral infection [116].

Since demyelination is usually caused by the autoimmune reaction triggered by an excessive and widespread inflammation [72], there are also findings of demyelinating lesions induced by SARS-CoV and associated with MS earlier in the pandemic. However, one case only histologically documented neuronal damage with perivascular lymphocytes and microglial reaction, associated with the $\mathrm{CD} 68+$ histiocytic population more represented than lymphocytes [71]. Moreover, pathological correlates are not strong, thus requiring more and systematic investigations in this "cutting-edge" topic. Finally, reduced T lymphocytes and lymphopenia in COVID-19 have been described, a finding which may put vulnerable individuals at risk for opportunistic infections, especially if this occurs in combination with steroid treatment. However, additional evidence is needed to support the vulnerability of subjects with COVID-19 to opportunistic infections [116].

\subsection{Comments and Outlooks}

Overall, neuropathological changes in patients with COVID-19 appear to be of a mild entity, neuroinflammatory signs being the most common finding, along with reactive gliosis, astrocytosis, and microglia activation [70].

While COVID-19 patients continue to be reported, the neuropathological pattern of ischemic/hypoxic injury, cerebral hemorrhage, and mild or moderate non-specific in- 
flammation are unlikely to vary [118] significantly. The identification of CoVs particles by electron microscopy is also difficult because of the similar appearance of normal cell structures, an aspect which has generated several controversies [118]. The inherent bias of autoptic exams for severe, fatal cases and institutional restrictions for morphological CNS assessment have also determined that some studies might have overestimated both the extent and frequency of neuropathological findings, whereas others might have underestimated them [119]. Finally, autopsies in children, which include the multisystem inflammatory syndrome, remain extremely rare. Although they are responsible for $<2 \%$ of all COVID-19 [120], neuropathological data from pediatric patients can significantly aid in disentangling the peculiar pathophysiological basis underlying the pediatric disease, including the typical immune-response, the degree of ischemic/hypoxic damage, and the hypercoagulability state of this age-group.

Further "hot topics" are the characterization of the effects of antiviral therapies (such as remdesivir), steroids (including dexamethasone), immunomodulatory medications (e.g., anti-interleukin-6), monoclonal antibodies, and anticoagulant agents on the brain [119]. Since therapeutic responses to COVID-19 vastly differ among centers, the understanding of how the different treatment options during hospitalization and after discharge might be responsible for the variability in both acute and long-term neurological manifestations and their histopathological correlates [121] remains. Regarding long-term sequelae, neuropathological findings in COVID-19 survivors are totally unstudied. Some CNS symptoms, such as asthenia, headache, myalgia, anosmia, and dysgeusia, may last for weeks or even months in a non-negligible portion of patients [122,123], and studies determining causes and mechanisms underlying long-term manifestations are required.

The persistence of symptoms or development of new symptoms related to SARSCoV-2 infection late in the course of COVID-19 is an increasingly recognized problem facing the infected population and health systems. "Long-COVID" or "COVID longhaulers" describes those persons who experience symptoms for more than 28 days after the diagnosis of SARS-CoV-2 infection [124]. Symptoms are as markedly heterogeneous as seen in acute disease and may be constant, fluctuating, or replaced by other symptoms of varying frequency and severity. Such multisystem involvement requires a holistic approach and, although many patients can be managed in primary care, others need rehabilitative care [124]. In particular, a significant proportion of patients report persistent and debilitating symptoms centered not only around fatigue but also including "brain fog", pain, breathlessness, and dysrhythmias, that extend several months in the postinfection period [125]. These symptoms are a characteristic of a well-documented and largely unexplained post-viral illness, i.e., the myalgic encephalomyelitis/chronic fatigue syndrome (ME/CFS).

The "long haulers" with ME/CFS, who do not make a straight-forward recovery in the post-viral period, probably reflect damage by the host response to the initial infection [126]. A severe host response (e.g., the "cytokine storm"), indeed, can give rise to oxidative and inflammatory damage and generalized oxidative stress. Pathophysiological changes in SARS-CoV-2 that enhance the production of reactive oxygen species might be ameliorated by free radical scavengers, also confirming that oxidative stress and SARS-CoV-2 pathogenesis may be closely linked [127] and that some antioxidant therapies might be of beneficial effect [128].

\subsection{Limitations}

The few studies available, which also differ in terms of methodology, is the main limitation of this review. Thus, the generalization of the findings reviewed here requires further validation given the low number of cases, the limited clinical data, and the lack of sex- and age-matched controls. To date, therefore, the etiological link between SARS-CoV-2 infection and autoptic brain correlates remains inconclusive. In particular, the possibility of primary viral-related damage on neurons and glia needs to be validated by systematic identifications of the viral genome within the brain or at the CSF. Surely, the triggering 
of an abnormal immune response, together with the release of neurochemical factors and inflammatory mediators, significantly contribute to BBB disruption, changes in brain homeostasis, and clinical manifestations.

Other critical aspects regard the sensitivity and specificity of the diagnostic techniques used, the unavoidable effect of unspecific post-mortem phenomena on brain tissue, and the challenges in studying a large number of people or particular age groups (such as children and young adults).

Further, larger and independent works on autoptic exams, integrated with clinical, laboratory, CSF, imaging, and general autoptic data, are needed to elucidate the impact of SARS-CoV-2 on CNS and its role in the process, progression, and mortality of COVID-19.

\section{Conclusions}

Notwithstanding the limited evidence available and the heterogeneity of the studies, in this review, we provided a preliminary description of the complex relationship between SARS-CoV-2 and CNS sequelae. Despite the exponentially increasing number of publications on COVID-19, the lack of well-defined pathophysiology and systematic neuropathology of long-term neurological consequences of SARS-CoV-2 still stands. Given the peculiar features of the CNS and the challenges in collecting samples, autopsy remains the gold standard exam for studying any primary CNS disorder and its involvement in the course of systemic diseases, such as COVID-19. More autopsies would mean further knowledge, accurate diagnosis, new therapeutic approaches, and improvement in the survivors' quality of life. In this tragic pandemic, lessons from dead people can rescue lives.

Author Contributions: Conceptualization, G.L and G.M.; methodology, M.D.N.; validation, A.L., M.P. and R.B.; formal analysis, F.F.; investigation, M.F.; resources, F.D.S.; writing-original draft preparation, F.F. and M.D.N.; writing-review and editing, A.L. and G.L.; visualization, M.F. and F.D.S.; supervision, M.P. and R.B.; project administration, G.M. All authors have read and agreed to the published version of the manuscript.

Funding: This research received no external funding.

Institutional Review Board Statement: Not applicable.

Informed Consent Statement: Not applicable.

Conflicts of Interest: The authors declare no conflict of interest.

\section{Appendix A}

Table A1. Autopsy studies in COVID-19 individuals without brain involvement.

\begin{tabular}{ccc}
\hline Study & P/CV/C & Other Organs \\
\hline Tian et al., 2020 [80] & $\sqrt{ }$ & \\
Danzi et al., 2020 [79] & $\sqrt{ }$ & Kidney \\
Su et al., 2020 [81] & & Kidney \\
Peleg et al., 2020 [82] & $\sqrt{ }$ & \\
Zhang et al., 2020 [83] & $\sqrt{ }$ & Kidney, spleen, liver \\
Yao et al., 2020 [84] & $\sqrt{ }$ & Kidney \\
Li et al., 2020 [85] & $\sqrt{ }$ & Placenta \\
Rossi et al., 2020 [86] & & Placenta \\
Wichmann et al., 2020 [87] & &
\end{tabular}


Table A1. Cont.

\begin{tabular}{ccc}
\hline Study & P/CV/C & Other Organs \\
\hline Varga et al., 2020 [90] & $\sqrt{ }$ & Kidney \\
Dolhnikoff et al., 2020 [91] & $\sqrt{ }$ & Skin \\
Magro et al., 2020 [92] & $\sqrt{ }$ & \\
Buja et al., 2020 [93] & $\sqrt{ }$ & \\
Ducloyer et al., 2020 [94] & $\sqrt{ }$ & \\
Lax et al., 2020 [95] & $\sqrt{ }$ & Liver \\
Suess and Hausmann 2020 [96] & $\sqrt{ }$ & Spleen \\
Flikweert et al., 2020 [97] & $\sqrt{ }$ & \\
Li et al., 2020 [98] & $\sqrt{ }$ & \\
Sonzogni et al., 2020 [99] & $\sqrt{ }$ & \\
Carsana et al., 2020. [100] & $\sqrt{ }$ & \\
Bradley et al., 2020 [101] & $\sqrt{ }$ & \\
Schaller et al., 2020 [102] & $\sqrt{ }$ & \\
Remmelink et al., 2020 [103] & $\sqrt{ }$ & \\
Nunes Duarte-Neto et al., 2020 [104] & $\sqrt{ }$ & \\
Prilutskiy et al., 2020 [105] & $\sqrt{ }$ & \\
Xu et al., 2020 [21] & $\sqrt{ }$ & \\
Konopka et al., 2020 [106] & $\sqrt{ }$ & \\
Yan et al., 2020 [107] & $\sqrt{ }$ & \\
Fitzek et al., 2020 [108] & $\sqrt{ }$ & \\
Rev Esp Patol. 2020 [78] & $\sqrt{ }$ & \\
Luo et al., 2020 [109] & $\sqrt{ }$ & \\
Tian et al., 2020 [110] & $\sqrt{ }$ & \\
Kuang et al., 2020 [111] & $\sqrt{ }$ & \\
Pernazza et al., 2020 [112] & & \\
Fox et al., 2020 [113] & & \\
Barton et al., 2020 [114] & & \\
Brook et al., 2020 [115] & & \\
\hline
\end{tabular}

Legend: P: pulmonary involvement; CV: cardiovascular involvement; C: coagulopathy.

\section{References}

1. Baig, A.M.; Khaleeq, A.; Ali, U.; Syeda, H. Evidence of the COVID-19 Virus Targeting the CNS: Tissue Distribution, Host-Virus Interaction, and Proposed Neurotropic Mechanisms. ACS Chem. Neurosci. 2020, 11, 995-998. [CrossRef] [PubMed]

2. Baig, A.M.; Sanders, E.C. Potential Neuroinvasive Pathways of SARS-CoV-2: Deciphering the Spectrum of Neurological Deficit Seen in Coronavirus Disease-2019 (COVID-19). J. Med. Virol. 2020, 92, 1845-1857. [CrossRef] [PubMed]

3. Moriguchi, T.; Harii, N.; Goto, J.; Harada, D.; Sugawara, H.; Takamino, J.; Ueno, M.; Sakata, H.; Kondo, K.; Myose, N.; et al. A First Case of Meningitis/Encephalitis Associated with SARS-Coronavirus-2. Int. J. Infect. Dis. 2020, 94, 55-58. [CrossRef] [PubMed]

4. Bernard-Valnet, R.; Pizzarotti, B.; Anichini, A.; Demars, Y.; Russo, E.; Schmidhauser, M.; Cerutti-Sola, J.; Rossetti, A.O.; Du Pasquier, R. Two Patients with Acute Meningoencephalitis Concomitant with SARS-CoV-2 Infection. Eur. J. Neurol. 2020, 27, e43-e44. [CrossRef] [PubMed]

5. Ye, M.; Ren, Y.; Lv, T. Encephalitis as a Clinical Manifestation of COVID-19. Brain. Behav. Immun. 2020, 88, 945-946. [CrossRef]

6. Solomon, I.H.; Normandin, E.; Bhattacharyya, S.; Mukerji, S.S.; Keller, K.; Ali, A.S.; Adams, G.; Hornick, J.L.; Padera, R.F.; Sabeti, P. Neuropathological Features of Covid-19. N. Engl. J. Med. 2020, 383, 989-992. [CrossRef]

7. Hoffmann, M.; Schroeder, S.; Kleine-Weber, H.; Müller, M.A.; Drosten, C.; Pöhlmann, S. Nafamostat Mesylate Blocks Activation of SARS-CoV-2: New Treatment Option for COVID-19. Antimicrob. Agents Chemother. 2020, 64, e00754-20. [CrossRef]

8. Beyerstedt, S.; Casaro, E.B.; Rangel, É.B. COVID-19: Angiotensin-Converting Enzyme 2 (ACE2) Expression and Tissue Susceptibility to SARS-CoV-2 Infection. Eur. J. Clin. Microbiol. Infect. Dis. 2021, 1-15. [CrossRef]

9. Zubair, A.S.; McAlpine, L.S.; Gardin, T.; Farhadian, S.; Kuruvilla, D.E.; Spudich, S. Neuropathogenesis and Neurologic Manifestations of the Coronaviruses in the Age of Coronavirus Disease 2019: A Review. JAMA Neurol. 2020, 77, 1018-1027. [CrossRef]

10. Desforges, M.; Le Coupanec, A.; Brison, E.; Meessen-Pinard, M.; Talbot, P.J. Neuroinvasive and Neurotropic Human Respiratory Coronaviruses: Potential Neurovirulent Agents in Humans. Adv. Exp. Med. Biol. 2014, 807, 75-96. [CrossRef]

11. Gu, J.; Gong, E.; Zhang, B.; Zheng, J.; Gao, Z.; Zhong, Y.; Zou, W.; Zhan, J.; Wang, S.; Xie, Z.; et al. Multiple Organ Infection and the Pathogenesis of SARS. J. Exp. Med. 2005, 202, 415-424. [CrossRef] [PubMed]

12. Nicholls, J.M.; Butany, J.; Poon, L.L.M.; Chan, K.H.; Beh, S.L.; Poutanen, S.; Peiris, J.S.M.; Wong, M. Time Course and Cellular Localization of SARS-CoV Nucleoprotein and RNA in Lungs from Fatal Cases of SARS. PLoS Med. 2006, 3, e27. [CrossRef] [PubMed] 
13. Spiegel, M.; Schneider, K.; Weber, F.; Weidmann, M.; Hufert, F.T. Interaction of Severe Acute Respiratory Syndrome-Associated Coronavirus with Dendritic Cells. J. Gen. Virol. 2006, 87, 1953-1960. [CrossRef] [PubMed]

14. Trojanowicz, B.; Ulrich, C.; Kohler, F.; Bode, V.; Seibert, E.; Fiedler, R.; Girndt, M. Monocytic Angiotensin-Converting Enzyme 2 Relates to Atherosclerosis in Patients with Chronic Kidney Disease. Nephrol. Dial. Transplant. Off. Publ. Eur. Dial. Transpl. Assoc. Eur. Ren. Assoc. 2017, 32, 287-298. [CrossRef]

15. Sankowski, R.; Mader, S.; Valdés-Ferrer, S.I. Systemic Inflammation and the Brain: Novel Roles of Genetic, Molecular, and Environmental Cues as Drivers of Neurodegeneration. Front. Cell. Neurosci. 2015, 9, 28. [CrossRef]

16. Fazzini, E.; Fleming, J.; Fahn, S. Cerebrospinal Fluid Antibodies to Coronavirus in Patients with Parkinson's Disease. Mov. Disord. Off. J. Mov. Disord. Soc. 1992, 7, 153-158. [CrossRef]

17. Burks, J.S.; DeVald, B.L.; Jankovsky, L.D.; Gerdes, J.C. Two Coronaviruses Isolated from Central Nervous System Tissue of Two Multiple Sclerosis Patients. Science 1980, 209, 933-934. [CrossRef]

18. Salmi, A.; Ziola, B.; Hovi, T.; Reunanen, M. Antibodies to Coronaviruses OC43 and 229E in Multiple Sclerosis Patients. Neurology 1982, 32, 292-295. [CrossRef]

19. Dessau, R.B.; Lisby, G.; Frederiksen, J.L. Coronaviruses in Spinal Fluid of Patients with Acute Monosymptomatic Optic Neuritis. Acta Neurol. Scand. 1999, 100, 88-91. [CrossRef]

20. Kurtzke, J.F. Epidemiologic Evidence for Multiple Sclerosis as an Infection. Clin. Microbiol. Rev. 1993, 6, 382-427. [CrossRef]

21. Xu, Z.; Shi, L.; Wang, Y.; Zhang, J.; Huang, L.; Zhang, C.; Liu, S.; Zhao, P.; Liu, H.; Zhu, L.; et al. Pathological Findings of COVID-19 Associated with Acute Respiratory Distress Syndrome. Lancet Respir. Med. 2020, 8, 420-422. [CrossRef]

22. Payus, A.O.; Lin, C.L.S.; Noh, M.M.; Jeffree, M.S.; Ali, R.A. SARS-CoV-2 Infection of the Nervous System: A Review of the Literature on Neurological Involvement in Novel Coronavirus Disease-(COVID-19). Bosn. J. Basic Med. Sci. 2020, 20, 283-292. [CrossRef] [PubMed]

23. Pennisi, M.; Lanza, G.; Falzone, L.; Fisicaro, F.; Ferri, R.; Bella, R. SARS-CoV-2 and the Nervous System: From Clinical Features to Molecular Mechanisms. Int. J. Mol. Sci. 2020, 21, 5475. [CrossRef] [PubMed]

24. Montemurro, N.; Perrini, P. Will COVID-19 Change Neurosurgical Clinical Practice? Br. J. Neurosurg. 2020, 1-2. [CrossRef] [PubMed]

25. Chua, T.H.; Xu, Z.; King, N.K.K. Neurological Manifestations in COVID-19: A Systematic Review and Meta-Analysis. Brain Inj. 2020, 1-20. [CrossRef]

26. Di Carlo, D.T.; Montemurro, N.; Petrella, G.; Siciliano, G.; Ceravolo, R.; Perrini, P. Exploring the Clinical Association between Neurological Symptoms and COVID-19 Pandemic Outbreak: A Systematic Review of Current Literature. J. Neurol. 2020, 1-9. [CrossRef]

27. Ahmed, S.; Leurent, B.; Sampson, E.L. Risk Factors for Incident Delirium among Older People in Acute Hospital Medical Units: A Systematic Review and Meta-Analysis. Age Ageing 2014, 43, 326-333. [CrossRef]

28. Filatov, A.; Sharma, P.; Hindi, F.; Espinosa, P.S. Neurological Complications of Coronavirus Disease (COVID-19): Encephalopathy. Cureus 2020, 12, e7352. [CrossRef]

29. Mao, L.; Jin, H.; Wang, M.; Hu, Y.; Chen, S.; He, Q.; Chang, J.; Hong, C.; Zhou, Y.; Wang, D.; et al. Neurologic Manifestations of Hospitalized Patients With Coronavirus Disease 2019 in Wuhan, China. JAMA Neurol. 2020. [CrossRef]

30. Krishnan, V.; Leung, L.Y.; Caplan, L.R. A Neurologist's Approach to Delirium: Diagnosis and Management of Toxic Metabolic Encephalopathies. Eur. J. Intern. Med. 2014, 25, 112-116. [CrossRef]

31. Poyiadji, N.; Shahin, G.; Noujaim, D.; Stone, M.; Patel, S.; Griffith, B. COVID-19-Associated Acute Hemorrhagic Necrotizing Encephalopathy: CT and MRI Features. Radiology 2020, 201187. [CrossRef] [PubMed]

32. Ghosh, R.; Dubey, S.; Finsterer, J.; Chatterjee, S.; Ray, B.K. SARS-CoV-2-Associated Acute Hemorrhagic, Necrotizing Encephalitis (AHNE) Presenting with Cognitive Impairment in a 44-Year-Old Woman without Comorbidities: A Case Report. Am. J. Case Rep. 2020, 21, e925641. [CrossRef] [PubMed]

33. Kaya, Y.; Kara, S.; Akinci, C.; Kocaman, A.S. Transient Cortical Blindness in COVID-19 Pneumonia; a PRES-like Syndrome: Case Report. J. Neurol. Sci. 2020, 413, 116858. [CrossRef] [PubMed]

34. Kakadia, B.; Ahmed, J.; Siegal, T.; Jovin, T.G.; Thon, J.M. Mild Encephalopathy with Reversible Splenium Lesion (MERS) in a Patient with COVID-19. J. Clin. Neurosci. Off. J. Neurosurg. Soc. Australas. 2020, 79, 272-274. [CrossRef] [PubMed]

35. Carod-Artal, F.J. Neurological Complications of Coronavirus and COVID-19. Rev. Neurol. 2020, 70, 311-322. [CrossRef] [PubMed]

36. Li, Y.; Li, M.; Wang, M.; Zhou, Y.; Chang, J.; Xian, Y.; Wang, D.; Mao, L.; Jin, H.; Hu, B. Acute Cerebrovascular Disease Following COVID-19: A Single Center, Retrospective, Observational Study. Stroke Vasc. Neurol. 2020, 5, 385-389. [CrossRef]

37. Oxley, T.J.; Mocco, J.; Majidi, S.; Kellner, C.P.; Shoirah, H.; Singh, I.P.; De Leacy, R.A.; Shigematsu, T.; Ladner, T.R.; Yaeger, K.A.; et al. Large-Vessel Stroke as a Presenting Feature of Covid-19 in the Young. N. Engl. J. Med. 2020, 382, e60. [CrossRef]

38. Manousakis, G.; Jensen, M.B.; Chacon, M.R.; Sattin, J.A.; Levine, R.L. The Interface between Stroke and Infectious Disease: Infectious Diseases Leading to Stroke and Infections Complicating Stroke. Curr. Neurol. Neurosci. Rep. 2008, 9, 28. [CrossRef]

39. Ding, Y.; Wang, H.; Shen, H.; Li, Z.; Geng, J.; Han, H.; Cai, J.; Li, X.; Kang, W.; Weng, D.; et al. The Clinical Pathology of Severe Acute Respiratory Syndrome (SARS): A Report from China. J. Pathol. 2003, 200, 282-289. [CrossRef]

40. Giacomelli, A.; Pezzati, L.; Conti, F.; Bernacchia, D.; Siano, M.; Oreni, L.; Rusconi, S.; Gervasoni, C.; Ridolfo, A.L.; Rizzardini, G.; et al. Self-Reported Olfactory and Taste Disorders in SARS-CoV-2 Patients: A Cross-Sectional Study. Clin. Infect. Dis. Off. Publ. Infect. Dis. Soc. Am. 2020, 71, 889-890. [CrossRef] 
41. Vaira, L.A.; Salzano, G.; Deiana, G.; De Riu, G. Anosmia and Ageusia: Common Findings in COVID-19 Patients. The Laryngoscope 2020, 130, 1787. [CrossRef] [PubMed]

42. Lechien, J.R.; Chiesa-Estomba, C.M.; De Siati, D.R.; Horoi, M.; Le Bon, S.D.; Rodriguez, A.; Dequanter, D.; Blecic, S.; El Afia, F.; Distinguin, L.; et al. Olfactory and Gustatory Dysfunctions as a Clinical Presentation of Mild-to-Moderate Forms of the Coronavirus Disease (COVID-19): A Multicenter European Study. Eur. Arch. Oto-Rhino-Laryngol. 2020, 277, 2251-2261. [CrossRef] [PubMed]

43. Hanley, B.; Lucas, S.B.; Youd, E.; Swift, B.; Osborn, M. Autopsy in Suspected COVID-19 Cases. J. Clin. Pathol. 2020, 73, $239-242$. [CrossRef] [PubMed]

44. Infection Prevention and Control for the Safe Management of a Dead Body in the Context of COVID-19: Interim Guidance. Available online: https: / / www.who.int/publications-detail-redirect/infection-prevention-and-control-for-the-safe-managementof-a-dead-body-in-the-context-of-covid-19-interim-guidance (accessed on 20 December 2020).

45. CDC Collection and Submission of Postmortem Specimens from Deceased Persons with Confirmed or Suspected COVID-19. Postmortem Guidance. Available online: https:/ /www.cdc.gov/coronavirus/2019-ncov/hcp/guidance-postmortem-specimens. html (accessed on 1 February 2021).

46. Osborn, D.M. Autopsy Practice Relating to Possible Cases of COVID-19 (2019-NCov, Novel Coronavirus from China 2019/2020); The Royal College of Pathologists: London, UK, 2020.

47. Franca, R.A.; Ugga, L.; Guadagno, E.; Russo, D.; Del Basso De Caro, M. Neuroinvasive Potential of SARS-CoV2 with Neuroradiological and Neuropathological Findings: Is the Brain a Target or a Victim? APMIS Acta Pathol. Microbiol. Immunol. Scand. 2020. [CrossRef] [PubMed]

48. Shellhaas, R.A. Neurologists and COVID-19: A Note on Courage in a Time of Uncertainty. Neurology 2020, 94, 855-857. [CrossRef]

49. Montalvan, V.; Lee, J.; Bueso, T.; De Toledo, J.; Rivas, K. Neurological Manifestations of COVID-19 and Other Coronavirus Infections: A Systematic Review. Clin. Neurol. Neurosurg. 2020, 194, 105921. [CrossRef]

50. Mansueto, G.; Niola, M.; Napoli, C. Can COVID 2019 Induce a Specific Cardiovascular Damage or It Exacerbates Pre-Existing Cardiovascular Diseases? Pathol. Res. Pract. 2020, 216, 153086. [CrossRef]

51. Mansueto, G. COVID-19: Brief Check through the Pathologist's Eye (Autopsy Archive). Pathol. Res. Pract. 2020, 216, 153195. [CrossRef]

52. Napoli, C.; Tritto, I.; Mansueto, G.; Coscioni, E.; Ambrosio, G. Immunosenescence Exacerbates the COVID-19. Arch. Gerontol. Geriatr. 2020, 90, 104174. [CrossRef]

53. Napoli, C.; Tritto, I.; Benincasa, G.; Mansueto, G.; Ambrosio, G. Cardiovascular Involvement during COVID-19 and Clinical Implications in Elderly Patients. A Review. Ann. Med. Surg. 2020, 57, 236-243. [CrossRef]

54. Mansueto, G.; Benincasa, G.; Capasso, E.; Graziano, V.; Russo, M.; Niola, M.; Napoli, C.; Buccelli, C. Autoptic Findings of Sudden Cardiac Death (SCD) in Patients with Arrhythmogenic Ventricular Cardiomiopathy (AVC) from Left Ventricle and Biventricular Involvement. Pathol. Res. Pract. 2020, 216, 153269. [CrossRef] [PubMed]

55. Mansueto, G.; Costa, D.; Capasso, E.; Varavallo, F.; Brunitto, G.; Caserta, R.; Esposito, S.; Niola, M.; Sardu, C.; Marfella, R.; et al. The Dating of Thrombus Organization in Cases of Pulmonary Embolism: An Autopsy Study. BMC Cardiovasc. Disord. 2019, 19, 250. [CrossRef] [PubMed]

56. Paternoster, M.; Capasso, E.; Di Lorenzo, P.; Mansueto, G. Fatal Exertional Rhabdomyolysis. Literature Review and Our Experience in Forensic Thanatology. Leg. Med. Tokyo Jpn. 2018, 35, 12-17. [CrossRef]

57. Russo, C.V.; Saccà, F.; Paternoster, M.; Buonomo, A.R.; Gentile, I.; Scotto, R.; Brescia Morra, V.; Mansueto, G. Post-Mortem Diagnosis of Invasive Pulmonary Aspergillosis after Alemtuzumab Treatment for Multiple Sclerosis. Mult. Scler. Houndmills Basingstoke Engl. 2020, 26, 123-126. [CrossRef] [PubMed]

58. Mansueto, G.; Capasso, E.; Buccelli, C.; Niola, M. Pulmonary Eosinophilic Inflammatory Infiltration Post-Intensive Care in a Nearly Drowned Young Man with Papillary Fibroelastoma: A Rare Complication Discovered by Forensic Autopsy. Front. Med. 2018, 4, 253. [CrossRef]

59. Huang, C.; Wang, Y.; Li, X.; Ren, L.; Zhao, J.; Hu, Y.; Zhang, L.; Fan, G.; Xu, J.; Gu, X.; et al. Clinical Features of Patients Infected with 2019 Novel Coronavirus in Wuhan, China. Lancet Lond. Engl. 2020, 395, 497-506. [CrossRef]

60. Vaduganathan, M.; Vardeny, O.; Michel, T.; McMurray, J.J.V.; Pfeffer, M.A.; Solomon, S.D. Renin-Angiotensin-Aldosterone System Inhibitors in Patients with Covid-19. N. Engl. J. Med. 2020, 382, 1653-1659. [CrossRef]

61. Patel, A.B.; Verma, A. COVID-19 and Angiotensin-Converting Enzyme Inhibitors and Angiotensin Receptor Blockers: What Is the Evidence? JAMA 2020, 323, 1769-1770. [CrossRef]

62. Madjid, M.; Safavi-Naeini, P.; Solomon, S.D.; Vardeny, O. Potential Effects of Coronaviruses on the Cardiovascular System: A Review. JAMA Cardiol. 2020, 5, 831-840. [CrossRef]

63. Wenzhong, L.; Hualan, L. COVID-19:Attacks the 1-Beta Chain of Hemoglobin and Captures the Porphyrin to Inhibit Human Heme Metabolism. Am. Chem. Soc. 2020. [CrossRef]

64. Kanberg, N.; Ashton, N.J.; Andersson, L.-M.; Yilmaz, A.; Lindh, M.; Nilsson, S.; Price, R.W.; Blennow, K.; Zetterberg, H.; Gisslén, M. Neurochemical Evidence of Astrocytic and Neuronal Injury Commonly Found in COVID-19. Neurology 2020, 95, e1754-e1759. [CrossRef] [PubMed]

65. Tsai, L.-K.; Hsieh, S.-T.; Chang, Y.-C. Neurological Manifestations in Severe Acute Respiratory Syndrome. Acta Neurol. Taiwanica 2005, 14, 113-119. 
66. Román, G.C.; Spencer, P.S.; Reis, J.; Buguet, A.; Faris, M.E.A.; Katrak, S.M.; Láinez, M.; Medina, M.T.; Meshram, C.; Mizusawa, H.; et al. The Neurology of COVID-19 Revisited: A Proposal from the Environmental Neurology Specialty Group of the World Federation of Neurology to Implement International Neurological Registries. J. Neurol. Sci. 2020, 414, 116884. [CrossRef] [PubMed]

67. Hung, E.C.W.; Chim, S.S.C.; Chan, P.K.S.; Tong, Y.K.; Ng, E.K.O.; Chiu, R.W.K.; Leung, C.-B.; Sung, J.J.Y.; Tam, J.S.; Lo, Y.M.D. Detection of SARS Coronavirus RNA in the Cerebrospinal Fluid of a Patient with Severe Acute Respiratory Syndrome. Clin. Chem. 2003, 49, 2108-2109. [CrossRef]

68. Stoyanov, G.S.; Lyutfi, E.; Dzhenkov, D.L.; Petkova, L. Acute Necrotizing Encephalitis in Viral Respiratory Tract Infection: An Autopsy Case Report. Cureus 2020, 12, e8070. [CrossRef]

69. Paniz-Mondolfi, A.; Bryce, C.; Grimes, Z.; Gordon, R.E.; Reidy, J.; Lednicky, J.; Sordillo, E.M.; Fowkes, M. Central Nervous System Involvement by Severe Acute Respiratory Syndrome Coronavirus-2 (SARS-CoV-2). J. Med. Virol. 2020, 92, 699-702. [CrossRef]

70. Matschke, J.; Lütgehetmann, M.; Hagel, C.; Sperhake, J.P.; Schröder, A.S.; Edler, C.; Mushumba, H.; Fitzek, A.; Allweiss, L.; Dandri, M.; et al. Neuropathology of Patients with COVID-19 in Germany: A Post-Mortem Case Series. Lancet Neurol. 2020, 19, 919-929. [CrossRef]

71. Al-Dalahmah, O.; Thakur, K.T.; Nordvig, A.S.; Prust, M.L.; Roth, W.; Lignelli, A.; Uhlemann, A.-C.; Miller, E.H.; KunnathVelayudhan, S.; Del Portillo, A.; et al. Neuronophagia and Microglial Nodules in a SARS-CoV-2 Patient with Cerebellar Hemorrhage. Acta Neuropathol. Commun. 2020, 8, 147. [CrossRef]

72. Reichard, R.R.; Kashani, K.B.; Boire, N.A.; Constantopoulos, E.; Guo, Y.; Lucchinetti, C.F. Neuropathology of COVID-19: A Spectrum of Vascular and Acute Disseminated Encephalomyelitis (ADEM)-like Pathology. Acta Neuropathol. (Berl.) 2020, 1-6. [CrossRef]

73. Bryce, C.; Grimes, Z.; Pujadas, E.; Ahuja, S.; Beasley, M.B.; Albrecht, R.; Hernandez, T.; Stock, A.; Zhao, Z.; Rasheed, M.A.; et al. Pathophysiology of SARS-CoV-2: Targeting of Endothelial Cells Renders a Complex Disease with Thrombotic Microangiopathy and Aberrant Immune Response. The Mount Sinai COVID-19 Autopsy Experience. medRxiv 2020. [CrossRef]

74. Spence, J.D.; de Freitas, G.R.; Pettigrew, L.C.; Ay, H.; Liebeskind, D.S.; Kase, C.S.; Del Brutto, O.H.; Hankey, G.J.; Venketasubramanian, N. Mechanisms of Stroke in COVID-19. Cerebrovasc. Dis. Basel Switz. 2020, 49, 451-458. [CrossRef] [PubMed]

75. Koh, J.S.; De Silva, D.A.; Quek, A.M.L.; Chiew, H.J.; Tu, T.M.; Seet, C.Y.H.; Hoe, R.H.M.; Saini, M.; Hui, A.C.-F.; Angon, J.; et al. Neurology of COVID-19 in Singapore. J. Neurol. Sci. 2020, 418, 117118. [CrossRef] [PubMed]

76. Requena, M.; Olivé-Gadea, M.; Muchada, M.; García-Tornel, Á.; Deck, M.; Juega, J.; Boned, S.; Rodríguez-Villatoro, N.; Piñana, C.; Pagola, J.; et al. COVID-19 and Stroke: Incidence and Etiological Description in a High-Volume Center. J. Stroke Cerebrovasc. Dis. 2020, 29, 105225. [CrossRef] [PubMed]

77. Abdelaziz, O.S.; Waffa, Z. Neuropathogenic Human Coronaviruses: A Review. Rev. Med. Virol. 2020, 30, e02118. [CrossRef] [PubMed]

78. The First COVID-19 Autopsy in Spain Performed during the Early Stages of the Pandemic. Rev. Espanola Patol. 2020, 53, 182-187. [CrossRef]

79. Danzi, G.B.; Loffi, M.; Galeazzi, G.; Gherbesi, E. Acute Pulmonary Embolism and COVID-19 Pneumonia: A Random Association? Eur. Heart J. 2020, 41, 1858. [CrossRef]

80. Tian, S.; Xiong, Y.; Liu, H.; Niu, L.; Guo, J.; Liao, M.; Xiao, S.-Y. Pathological Study of the 2019 Novel Coronavirus Disease (COVID-19) through Postmortem Core Biopsies. Mod. Pathol. 2020, 33, 1007-1014. [CrossRef]

81. Su, H.; Yang, M.; Wan, C.; Yi, L.-X.; Tang, F.; Zhu, H.-Y.; Yi, F.; Yang, H.-C.; Fogo, A.B.; Nie, X.; et al. Renal Histopathological Analysis of 26 Postmortem Findings of Patients with COVID-19 in China. Kidney Int. 2020, 98, 219-227. [CrossRef]

82. Peleg, Y.; Kudose, S.; D’Agati, V.; Siddall, E.; Ahmad, S.; Kisselev, S.; Gharavi, A.; Canetta, P. Acute Kidney Injury Due to Collapsing Glomerulopathy Following COVID-19 Infection. Kidney Int. Rep. 2020, 5, 940-945. [CrossRef]

83. Zhang, H.; Zhou, P.; Wei, Y.; Yue, H.; Wang, Y.; Hu, M.; Zhang, S.; Cao, T.; Yang, C.; Li, M.; et al. Histopathologic Changes and SARS-CoV-2 Immunostaining in the Lung of a Patient With COVID-19. Ann. Intern. Med. 2020, 172, 629-632. [CrossRef]

84. Yao, X.H.; Li, T.Y.; He, Z.C.; Ping, Y.F.; Liu, H.W.; Yu, S.C.; Mou, H.M.; Wang, L.H.; Zhang, H.R.; Fu, W.J.; et al. A pathological report of three COVID-19 cases by minimal invasive autopsies. Zhonghua Bing Li Xue Za Zhi 2020, 49, 411-417. [CrossRef] [PubMed]

85. Li, G.; Fox, S.E.; Summa, B.; Wenk, C.; Akmatbekov, A.; Harbert, J.L.; Heide, R.S.V.; Brown, J.Q. Multiscale 3-Dimensional Pathology Findings of COVID-19 Diseased Lung Using High-Resolution Cleared Tissue Microscopy. bioRxiv 2020. [CrossRef]

86. Rossi, G.M.; Delsante, M.; Pilato, F.P.; Gnetti, L.; Gabrielli, L.; Rossini, G.; Re, M.C.; Cenacchi, G.; Affanni, P.; Colucci, M.E.; et al. Kidney Biopsy Findings in a Critically Ill COVID-19 Patient With Dialysis-Dependent Acute Kidney Injury: A Case Against "SARS-CoV-2 Nephropathy. " Kidney Int. Rep. 2020, 5, 1100-1105. [CrossRef] [PubMed]

87. Wichmann, D.; Sperhake, J.-P.; Lütgehetmann, M.; Steurer, S.; Edler, C.; Heinemann, A.; Heinrich, F.; Mushumba, H.; Kniep, I.; Schröder, A.S.; et al. Autopsy Findings and Venous Thromboembolism in Patients With COVID-19. Ann. Intern. Med. 2020, 173(4). [CrossRef]

88. Shanes, E.D.; Mithal, L.B.; Otero, S.; Azad, H.A.; Miller, E.S.; Goldstein, J.A. Placental Pathology in COVID-19. Am. J. Clin. Pathol. 2020, 154, 23-32. [CrossRef] [PubMed] 
89. Hosier, H.; Farhadian, S.F.; Morotti, R.A.; Deshmukh, U.; Lu-Culligan, A.; Campbell, K.H.; Yasumoto, Y.; Vogels, C.B.; CasanovasMassana, A.; Vijayakumar, P.; et al. SARS-CoV-2 Infection of the Placenta. J. Clin. Investig. 2020, 130, 4947-4953. [CrossRef] [PubMed]

90. Varga, Z.; Flammer, A.J.; Steiger, P.; Haberecker, M.; Andermatt, R.; Zinkernagel, A.S.; Mehra, M.R.; Schuepbach, R.A.; Ruschitzka, F.; Moch, H. Endothelial Cell Infection and Endotheliitis in COVID-19. Lancet Lond. Engl. 2020, 395, 1417-1418. [CrossRef]

91. Dolhnikoff, M.; Duarte-Neto, A.N.; de Almeida Monteiro, R.A.; da Silva, L.F.F.; de Oliveira, E.P.; Saldiva, P.H.N.; Mauad, T.; Negri, E.M. Pathological Evidence of Pulmonary Thrombotic Phenomena in Severe COVID-19. J. Thromb. Haemost. JTH 2020, 18, 1517-1519. [CrossRef]

92. Magro, C.; Mulvey, J.J.; Berlin, D.; Nuovo, G.; Salvatore, S.; Harp, J.; Baxter-Stoltzfus, A.; Laurence, J. Complement Associated Microvascular Injury and Thrombosis in the Pathogenesis of Severe COVID-19 Infection: A Report of Five Cases. Transl. Res. 2020, 220, 1-13. [CrossRef]

93. Buja, L.M.; Wolf, D.A.; Zhao, B.; Akkanti, B.; McDonald, M.; Lelenwa, L.; Reilly, N.; Ottaviani, G.; Elghetany, M.T.; Trujillo, D.O.; et al. The Emerging Spectrum of Cardiopulmonary Pathology of the Coronavirus Disease 2019 (COVID-19): Report of 3 Autopsies from Houston, Texas, and Review of Autopsy Findings from Other United States Cities. Cardiovasc. Pathol. 2020, 48, 107233. [CrossRef]

94. Ducloyer, M.; Gaborit, B.; Toquet, C.; Castain, L.; Bal, A.; Arrigoni, P.P.; Lecomte, R.; Clement, R.; Sagan, C. Complete Post-Mortem Data in a Fatal Case of COVID-19: Clinical, Radiological and Pathological Correlations. Int. J. Legal Med. 2020, 134, $2209-2214$. [CrossRef] [PubMed]

95. Lax, S.F.; Skok, K.; Zechner, P.; Kessler, H.H.; Kaufmann, N.; Koelblinger, C.; Vander, K.; Bargfrieder, U.; Trauner, M. Pulmonary Arterial Thrombosis in COVID-19 With Fatal Outcome: Results From a Prospective, Single-Center, Clinicopathologic Case Series. Ann. Intern. Med. 2020. [CrossRef] [PubMed]

96. Suess, C.; Hausmann, R. Gross and Histopathological Pulmonary Findings in a COVID-19 Associated Death during Self-Isolation. Int. J. Legal Med. 2020, 1-6. [CrossRef] [PubMed]

97. Flikweert, A.W.; Grootenboers, M.J.J.H.; Yick, D.C.Y.; du Mée, A.W.F.; van der Meer, N.J.M.; Rettig, T.C.D.; Kant, M.K.M. Late Histopathologic Characteristics of Critically Ill COVID-19 Patients: Different Phenotypes without Evidence of Invasive Aspergillosis, a Case Series. J. Crit. Care 2020, 59, 149-155. [CrossRef] [PubMed]

98. Li, S.; Jiang, L.; Li, X.; Lin, F.; Wang, Y.; Li, B.; Jiang, T.; An, W.; Liu, S.; Liu, H.; et al. Clinical and Pathological Investigation of Patients with Severe COVID-19. JCI Insight 2020, 5, e138070. [CrossRef] [PubMed]

99. Sonzogni, A.; Previtali, G.; Seghezzi, M.; Grazia Alessio, M.; Gianatti, A.; Licini, L.; Morotti, D.; Zerbi, P.; Carsana, L.; Rossi, R.; et al. Liver Histopathology in Severe COVID 19 Respiratory Failure Is Suggestive of Vascular Alterations. Liver Int. 2020, 40, 2110-2116. [CrossRef]

100. Carsana, L.; Sonzogni, A.; Nasr, A.; Rossi, R.S.; Pellegrinelli, A.; Zerbi, P.; Rech, R.; Colombo, R.; Antinori, S.; Corbellino, M.; et al. Pulmonary Post-Mortem Findings in a Series of COVID-19 Cases from Northern Italy: A Two-Centre Descriptive Study. Lancet Infect. Dis. 2020, 20, 1135-1140. [CrossRef]

101. Bradley, B.T.; Maioli, H.; Johnston, R.; Chaudhry, I.; Fink, S.L.; Xu, H.; Najafian, B.; Deutsch, G.; Lacy, J.M.; Williams, T.; et al. Histopathology and Ultrastructural Findings of Fatal COVID-19 Infections in Washington State: A Case Series. Lancet Lond. Engl. 2020, 396, 320-332. [CrossRef]

102. Schaller, T.; Hirschbühl, K.; Burkhardt, K.; Braun, G.; Trepel, M.; Märkl, B.; Claus, R. Postmortem Examination of Patients With COVID-19. JAMA 2020, 323, 2518-2520. [CrossRef]

103. Remmelink, M.; De Mendonça, R.; D’Haene, N.; De Clercq, S.; Verocq, C.; Lebrun, L.; Lavis, P.; Racu, M.-L.; Trépant, A.-L.; Maris, C.; et al. Unspecific Post-Mortem Findings despite Multiorgan Viral Spread in COVID-19 Patients. Crit. Care Lond. Engl. 2020, 24, 495. [CrossRef]

104. Duarte-Neto, A.N.; Monteiro, R.A.A.; da Silva, L.F.F.; Malheiros, D.M.A.C.; de Oliveira, E.P.; Theodoro-Filho, J.; Pinho, J.R.R.; Gomes-Gouvêa, M.S.; Salles, A.P.M.; de Oliveira, I.R.S.; et al. Pulmonary and Systemic Involvement in COVID-19 Patients Assessed with Ultrasound-Guided Minimally Invasive Autopsy. Histopathology 2020, 77, 186-197. [CrossRef] [PubMed]

105. Prilutskiy, A.; Kritselis, M.; Shevtsov, A.; Yambayev, I.; Vadlamudi, C.; Zhao, Q.; Kataria, Y.; Sarosiek, S.R.; Lerner, A.; Sloan, J.M.; et al. SARS-CoV-2 Infection-Associated Hemophagocytic Lymphohistiocytosis. Am. J. Clin. Pathol. 2020, 154, 466-474. [CrossRef]

106. Konopka, K.E.; Wilson, A.; Myers, J.L. Postmortem Lung Findings in a Patient With Asthma and Coronavirus Disease 2019. Chest 2020, 158, e99-e101. [CrossRef]

107. Yan, R.; Zhang, Y.; Li, Y.; Xia, L.; Guo, Y.; Zhou, Q. Structural Basis for the Recognition of SARS-CoV-2 by Full-Length Human ACE2. Science 2020, 367, 1444-1448. [CrossRef] [PubMed]

108. Fitzek, A.; Sperhake, J.; Edler, C.; Schröder, A.S.; Heinemann, A.; Heinrich, F.; Ron, A.; Mushumba, H.; Lütgehetmann, M.; Püschel, K. Evidence for Systematic Autopsies in COVID-19 Positive Deceased. Rechtsmed. Berl. Ger. 2020, 1-6. [CrossRef] [PubMed]

109. Luo, W.-R.; Yu, H.; Gou, J.-Z.; Li, X.-X.; Sun, Y.; Li, J.-X.; He, J.-X.; Liu, L. Histopathologic Findings in the Explant Lungs of a Patient With COVID-19 Treated With Bilateral Orthotopic Lung Transplant. Transplantation 2020, 104, e329. [CrossRef] [PubMed]

110. Tian, S.; Hu, W.; Niu, L.; Liu, H.; Xu, H.; Xiao, S.-Y. Pulmonary Pathology of Early-Phase 2019 Novel Coronavirus (COVID-19) Pneumonia in Two Patients With Lung Cancer. J. Thorac. Oncol. Off. Publ. Int. Assoc. Study Lung Cancer 2020, 15, 700-704. [CrossRef] [PubMed] 
111. Kuang, D.; Xu, S.P.; Hu, Y.; Liu, C.; Duan, Y.Q.; Wang, G.P. [Pathological changes with novel coronavirus infection in lung cancer surgical specimen]. Zhonghua Bing Li Xue Za Zhi 2020, 49, 471-473. [CrossRef]

112. Pernazza, A.; Mancini, M.; Rullo, E.; Bassi, M.; De Giacomo, T.; Rocca, C.D.; d'Amati, G. Early Histologic Findings of Pulmonary SARS-CoV-2 Infection Detected in a Surgical Specimen. Virchows Arch. 2020, 1-6. [CrossRef]

113. Fox, S.E.; Akmatbekov, A.; Harbert, J.L.; Li, G.; Brown, J.Q.; Heide, R.S.V. Pulmonary and Cardiac Pathology in African American Patients with COVID-19: An Autopsy Series from New Orleans. Lancet Respir. Med. 2020, 8, 681-686. [CrossRef]

114. Barton, L.M.; Duval, E.J.; Stroberg, E.; Ghosh, S.; Mukhopadhyay, S. COVID-19 Autopsies, Oklahoma, USA. Am. J. Clin. Pathol. 2020, 153, 725-733. [CrossRef] [PubMed]

115. Brook, O.R.; Piper, K.G.; Mercado, N.B.; Gebre, M.S.; Barouch, D.H.; Busman-Sahay, K.; Starke, C.E.; Estes, J.D.; Martinot, A.J.; Wrijil, L.; et al. Feasibility and Safety of Ultrasound-Guided Minimally Invasive Autopsy in COVID-19 Patients. Abdom. Radiol. N. Y. 2020, 1-9. [CrossRef] [PubMed]

116. Al-Sarraj, S.; Troakes, C.; Hanley, B.; Osborn, M.; Richardson, M.P.; Hotopf, M.; Bullmore, E.; Everall, I.P. Invited Review: The Spectrum of Neuropathology in COVID-19. Neuropathol. Appl. Neurobiol. 2020. [CrossRef]

117. González-Pinto, T.; Luna-Rodríguez, A.; Moreno-Estébanez, A.; Agirre-Beitia, G.; Rodríguez-Antigüedad, A.; Ruiz-Lopez, M. Emergency Room Neurology in Times of COVID-19: Malignant Ischaemic Stroke and SARS-CoV-2 Infection. Eur. J. Neurol. 2020, 27, e35-e36. [CrossRef]

118. Miller, S.E.; Brealey, J.K. Visualization of Putative Coronavirus in Kidney. Kidney Int. 2020, 98, 231-232. [CrossRef]

119. Mukerji, S.S.; Solomon, I.H. What Can We Learn from Brain Autopsies in COVID-19? Neurosci. Lett. 2020, 742, 135528. [CrossRef]

120. Parri, N.; Lenge, M.; Buonsenso, D. Coronavirus Infection in Pediatric Emergency Departments (CONFIDENCE) Research Group Children with Covid-19 in Pediatric Emergency Departments in Italy. N. Engl. J. Med. 2020, 383, 187-190. [CrossRef]

121. Tsatsakis, A.; Calina, D.; Falzone, L.; Petrakis, D.; Mitrut, R.; Siokas, V.; Pennisi, M.; Lanza, G.; Libra, M.; Doukas, S.G.; et al. SARS-CoV-2 Pathophysiology and Its Clinical Implications: An Integrative Overview of the Pharmacotherapeutic Management of COVID-19. Food Chem. Toxicol. Int. J. Publ. Br. Ind. Biol. Res. Assoc. 2020, 146, 111769. [CrossRef]

122. Carfi, A.; Bernabei, R.; Landi, F. Gemelli Against COVID-19 Post-Acute Care Study Group Persistent Symptoms in Patients After Acute COVID-19. JAMA 2020, 324, 603-605. [CrossRef]

123. Tenforde, M.W. Symptom Duration and Risk Factors for Delayed Return to Usual Health Among Outpatients with COVID-19 in a Multistate Health Care Systems Network-United States, March-June 2020. MMWR Morb. Mortal. Wkly. Rep. 2020, 69, 993-998. [CrossRef]

124. Mendelson, M.; Nel, J.; Blumberg, L.; Madhi, S.A.; Dryden, M.; Stevens, W.; Venter, F.W.D. Long-COVID: An Evolving Problem with an Extensive Impact. S. Afr. Med. J. 2020, 111, 10-12. [CrossRef] [PubMed]

125. Marshall, M. The Lasting Misery of Coronavirus Long-Haulers. Nature 2020, 585, 339-341. [CrossRef] [PubMed]

126. Wood, E.; Hall, K.H.; Tate, W. Role of Mitochondria, Oxidative Stress and the Response to Antioxidants in Myalgic Encephalomyelitis/Chronic Fatigue Syndrome: A Possible Approach to SARS-CoV-2 "Long-Haulers"? Chronic Dis. Transl. Med. 2020. [CrossRef]

127. Delgado-Roche, L.; Mesta, F. Oxidative Stress as Key Player in Severe Acute Respiratory Syndrome Coronavirus (SARS-CoV) Infection. Arch. Med. Res. 2020, 51, 384-387. [CrossRef] [PubMed]

128. Mironova, G.D.; Belosludtseva, N.V.; Ananyan, M.A. Prospects for the Use of Regulators of Oxidative Stress in the Comprehensive Treatment of the Novel Coronavirus Disease 2019 (COVID-19) and Its Complications. Eur. Rev. Med. Pharmacol. Sci. 2020, 24, 8585-8591. [CrossRef] [PubMed] 